\title{
Turizmus és biztonság: a magyar lakosság utazási szokásaihoz köthető, biztonsággal kapcsolatos attitúdök reprezentatív vizsgálata
}

\author{
Szerzők: Csapó János - Törőcsik Mária²
}

Tudjuk, hogy a fogyasztói döntések szempontjai, illetve meghozataluk módjai idôrôl időre változnak, ezért a döntéshozóknak és a kutatóknak is újabb és újabb kérdéseket kell megvizsgálniuk, hogy releváns megállapításokat tehessenek. Bár mindig is jelen volt a desztinációválasztásban, a biztonság kérdésköre nem túl régen jelent meg fokozottabb jelentôséggel a döntési szempontok között. Azért nyert ma más jelentôséget ez a kérdéskör, mert napjainkban a turizmussal egyre több olyan térség érhetô el a szélesebb célközönség számára is, amelyek esetében relevánssá válik a biztonság vizsgálata, akár elsődleges szempontként kezelve azt. A tömegturizmus kedvelői nem vágynak kockázatra, sokkal inkább a kiszámíthatóságot preferálják, így számukra alapvetô a biztonság. Tudjuk, hogy a vásárlási döntések komplexek, és nem csupán egyetlen tényezô határozza meg a kimenetet, mégis célszerü időnként egy összetevôre koncentrálva feltenni az arra vonatkozó kérdéseket. Tanulmányunkban azt vizsgáljuk, mennyiben határozzák meg a magyar lakosság döntéseit a biztonság különböző területei, milyen szegmensek esetében játszanak kiemelt szerepet, és milyen arányú csoportok számára válnak sokadlagos kérdéssé. Munkánk alapja egy 2018-ban végzett országos, a felnôtt 15-74 éves lakosságra reprezentatív online megkérdezés adatbázisa. Ennek elemzésével jutunk eredményekhez.

Kulcsszavak: turizmus, biztonság, utazási szokások, Magyarország, reprezentatív felmérés.

\section{Bevezetés, célkitúzések}

A turizmus komplex rendszerének egyik legfontosabb tényezóje a biztonság jelenléte, mely számos témakört ölel fel a természeti katasztrófáktól és a pénzügyi folyamatoktól a terrorizmuson át a szálláshely-szolgáltatás vagy a közlekedés biztonságáig. Napjaink idegenforgalmában tehát a biztonság nem feltétlenül csak a terrorizmus, vagy a különböző konfliktus-zónák meghatározta kérdéseket veti fel (DÁVID et al. 2007, SÖNMEZ-GRAEFE 1998), szerepe jóval összetettebb felfogást kíván. E széles környezetében értelmezett kapcsolatrendszer a turizmus és a kockázatok, a turizmus és a veszélyek, illetve a turizmus és a biztonság témakörében veti fel napjaink idegenforgalmának kiemelt kérdéseit és folyamatait (BUJDOSÓ-GYÖRKI 2011).

A turisztikai világpiac térben és időben is jelentős változásokon ment keresztül, mind a menynyiségi, mind a minőségi összetevőket tekintve

\footnotetext{
' egyetemi docens, Pécsi Tudományegyetem, csapo.janos@ktk.pte.hu ${ }^{2}$ egyetemi tanár, Pécsi Tudományegyetem, torocsik.maria@ktk.pte.hu
}

(LENGYEL 2004). A kiéleződő versenyben a színvonalbeli, avagy a mind magasabb minőségi elvárásoknak történő megfelelés mellett a biztonság és a kockázatminimalizálás tekintetében is helyt kell állni (SCOTT et al. 2010).

Felismerve a témakör gyakorlati és szakmai aktualitását, jelen tanulmány célja a magyar lakosság utazási szokásaihoz köthetó biztonsággal kapcsolatos attitúdök reprezentatív vizsgálatának és az abból kimutatható legfontosabb eredményeknek a bemutatása.

\section{Kutatási módszerek}

A kutatás eredményei egy személyes és egy online módon végzett, országosan reprezentatív minta megkérdezése során létrehozott adatbázis elemzésén alapulnak. Az 1085 fős online megkérdezést 2018 áprilisában és májusában végeztük abból a célból, hogy generációs vetületben vizsgáljuk a magyar lakosság turizmussal kapcsolatos beállítódását. A 2001 fốs személyes megkérdezést szintén 2018 áprilisában és májusában végeztük abból a célból, hogy a magyar lakosság magatartását és véleményét több témakörrel kapcsolatban is megvizsgál- 
Lektorált tanulmányok

juk. Ezek a témakörök: ageing, egészségügyi innovációk, turizmus, étkezési szokások, kulturális idótöltés, életstílus. Jelen tanulmányban a turizmus és biztonság témakör eredményeit közöljük. Mindkét megkérdezés reprezentatív a 15-74 éves magyar lakosságra nem, korcsoportok (10 éves intervallumok) és a lakóhely régiója alapján.

$\mathrm{Az}$ eredmények feldolgozását két részben végeztük el: először az elsődleges (gyakorisági) elemzéseket mutatjuk be, melyeket a demográfiai háttérelemzések követnek. Ennek során statisztikai módszerekkel vizsgáljuk, hogy az egyes demográfiai csoportoknak az egyes kérdésekre adott válaszaiban vannak-e statisztikailag igazolható (úgynevezett szignifikáns) eltérések. Az elemzésbe bevont változók: nem, generációk, lakóhely településtípusa, iskolai végzettség foka, jövedelmi helyzet szubjektív megítélése.

Jelen tanulmány az online megkérdezés eredményeire alapozva készült, a személyes megkérdezés adataival csupán háttérként dolgoztunk. A teljes kutatás kiegészült három fókuszcsoportos vitával is, ami a felmerült „miért” kérdéseinket válaszolta meg.

\section{Szakirodalmi áttekintés}

Az új gazdasági súlypontok egyike az utóbbi évtizedekben a szolgáltatás szektor nemzetgazdaságon belüli látványos növekedése, azon belül pedig a turizmus szerepének megerősödése (AUBERT et al. 2007a, AUBERT 2010, DÁVID-KOVÁCS 2012, HALL 2004, MEYER 2011, LEW et al. 2008, MICHALKÓ 2010). Fontos továbbá megjegyezni, hogy a turizmus regionális kötődése, a lokalitás jelenléte igen lényeges, mivel a mindenkori attrakciók túlnyomó többsége egy adott hely, térség, természeti táj vonzeróire alapozva jön létre (AUBERT et al. 2007b, MICHALKÓ 2012, DÁVID et al. 2010, GERDESICS 2017). Azzal, hogy egy térség, lokáció turisztikai kínálatára megfeleló infra- és szuprastruktúra kiépítése is megvalósul, az idegenforgalom a területi folyamatok alakítójává is válik. Ezen folyamatok hatnak többek közt a településszerkezetre, a foglalkoztatásra, a térségi kapcsolatok alakítására és a környezet formálására, illetve befolyásolják az életmódot, az életminőséget is (GONDA 2016). Ezen társadalmi-gazdasági és környezeti jellemzók különböző mértékben biztonsági, kockázati tényezóket is magukban hordozhatnak, amelyek egyértelmúen befolyásolják a turistát az utazási döntésében (HALL et al. 2003, MAWBY 2000, TARLOW 2014).

A biztonság és a kockázatok, illetve a veszélyérzet, veszélyhelyzet témakörét vizsgálva kiemelendő azonban, hogy a turizmus területi viszonyait ez a kérdéskör nagymértékben képes befolyásolni. A turisták térbeli mozgásai átalakulnak, újabb desztinációk kerül(het)nek fel az utazók térképeire és korábban jól ismert régiók kerülhetnek le az utazók listájáról, ami természetesen a társadalmi-gazdasági folyamatokra is jelentős hatást gyakorol (TÖRŐCSIK-CSAPÓ 2018, WILKS et al. 2011).

A biztonság és a kockázat kérdésének jelenléte azonban nemcsak a térbeli folyamatokat, hanem a fogyasztói magatartást is erősen befolyásolja. A napjaink turizmusát befolyásoló nemzetközi és hazai trendek kapcsán a fogyasztó, azaz a turista magatartásának változása és annak új tendenciái egyre meghatározóbb szerepet töltenek be az idegenforgalom formálódásában, átalakulásában, ami hatványozottan igaz a biztonsági tényezők figyelembe vétele kapcsán (BOGÁROMI-MALOTA 2017). Mivel egyre inkább megkerülhetetlen, fontos a félelmek, kockázatok, biztonság kérdésének felvetése (TÖRŐCSIK-JAKOPÁNECZ 2011), melynek kapcsán gondolhatunk bármire a terrorfenyegetettségtől a zaklatáson át a kellemetlen élmények megéléséig. Léteznek olyan biztonsági kérdések és utazási kockázatok, amelyeket egy turisztikai vállalkozás önállóan nem képes kezelni, azonban léteznek olyan problémák is, amelyeket kelló empátiával saját eróból meg tud oldani. Egyre inkább trend, hogy az utazók önállóan szervezik, és akár teljesen egyedül élik végig az útjaikat (solo travel), amihez nagyon fontos tudni azt, hol vannak biztos pontok, olyan helyek, ahol védelmet érezhetnek, így szüntetve meg az esetleges félelmeiket már a tervezés fázisában (BIANCHI 2016, HEIMTUNABELSEN 2014).

A hazai viszonyok tekintetében kiemelendô, hogy Magyarország társadalmi-gazdasági életében, és nem utolsó sorban nemzetközi imázsában is komoly szerepet tölt be a turizmus, ezért napjaink felgyorsult gazdasági-társadalmi folyamatait megélve és vizsgálva különösen fontos meghatározni az idegenforgalmat befolyásoló biztonsági, biztonságpolitikai kérdéseket (BUJDOSÓ-GYÖRKI 2011). Ezt a trendet felismerve a magyar állam képviselői rendre hangsúlyozzák a különbözó politikai és szakmai fórumokon, hogy a biztonság és kockázatok szemszögéből hazánk kiemelkedóen jó pozíciókkal rendelkezik, amit a Nemzeti Turizmusfejlesztési Stratégia 2030 is kiemelt kérdéskörnek tekint, lévén ezt a vonatkozást hangsúlyozza a jövő́t meghatározó legfontosabb globális trendek és kihívások között. A stratégiában 26-szor kerül elő a biztonság kérdése, nyomatékosítva, hogy Magyarország biztonságos desztináció. Ennek egyre nagyobb szerepe van az utazók döntésében, illetve a világesemények helyszínérôl való döntések kapcsán is kiemelt figyelmet kap (MAGYAR TURISZTIKAI ÜGYNÖKSÉG 2017). 


\section{A kutatás eredményei}

Az online kutatás folyamán az első kérdéscsoportban arra voltunk kíváncsiak, hogy a biztonság milyen szerepet tölt be a válaszadóknál az utazásaik során (1. ábra). A kérdéscsoport első részében feltett kérdésekre adott válaszok tanúsága alapján a válaszadók legnagyobb része (43\%, 467 fó) egyáltalán nem tölt le speciális applikációkat - amelyek könnyebbé, biztonságosabbá tehetik az útjukat az utazásaik folyamán. Ennél a kérdésnél a kevéssé egyetértők aránya viszonylag magas volt (2-es értéket 16\%, 3-as értéket 18\% adott meg). Az összes válaszadó $8 \%$-a viszont teljes mértékben egyetért az állítással, azaz utazásaik során speciális applikációkat töltenek le.

Ugyanakkor a válaszadók az utazásaik kapcsán már elózetesen nagymértékben tájékozódnak a meglátogatni tervezett terület biztonsági helyzetéről, hiszen a legtöbben (31\%, 332 fő) teljes mértékben egyetértettek ezzel az állítással, de a 3-as és 4 -es értékeket adók száma is magas volt $(23 \%$, illetve $28 \%$ ). Az utazásaik előtt tehát nagyon kevesen $(6 \%, 65$ fó) nem tájékozódnak az adott terület biztonsági helyzetéról.

Hasonló arányokat tapasztaltunk azon válaszok terén is, amikor arra voltunk kíváncsiak, hogy a válaszadók utazási döntését mennyiben befolyásolja, hogy az adott ország biztonságos-e. A legtöbben (36\%, 394 fó) teljes mértékben egyetértettek az állítással, de a 3-as és 4-es értékeket adók száma is magas volt (21, illetve $27 \%$ ). Az utazási döntését csak nagyon kevés válaszadónak $(6 \%, 61$ fô) nem határozza meg semmilyen mértékben sem az, hogy mennyire biztonságos az adott ország.

A következókben arra voltunk kíváncsiak, hogy volt-e már olyan helyzet a válaszadók életében, hogy valahová azért nem utaztak el, mert hallottak ottani biztonsági problémákról. Amellett, hogy ennél a kérdésnél a szokásos 4\%-5\%-nál jóval magasabb volt a nem válaszolók aránya (11\%), a válaszadók legnagyobb csoportja (28\%, 300 fő) egyáltalán nem értett egyet az állítással, tehát még sosem járt úgy az utazásai folyamán, hogy biztonsági problémák miatt ne utazott volna el. A második legmagasabb sokaság az ezzel éppen ellentétes tapasztalatú csoport volt, hiszen a válaszadók 25\%-ával már megtörtént, hogy valamely biztonsági probléma miatt nem utazott el egy területre. A kérdésre bizonytalanul válaszolók aránya viszonylag alacsony volt (2-es érték 10\%, 3-as és 4-es érték 13\%).

Az előző kérdést kissé megfordítva, a következőkben arra kérdeztünk rá, hogy volt-e már úgy a válaszadók életében, hogy tudtak a választott turisztikai desztinációban egy adott biztonsági problémáról, ennek ellenére mégis elutaztak

\section{A turizmus és biztonság kérdéskörének eredményei}

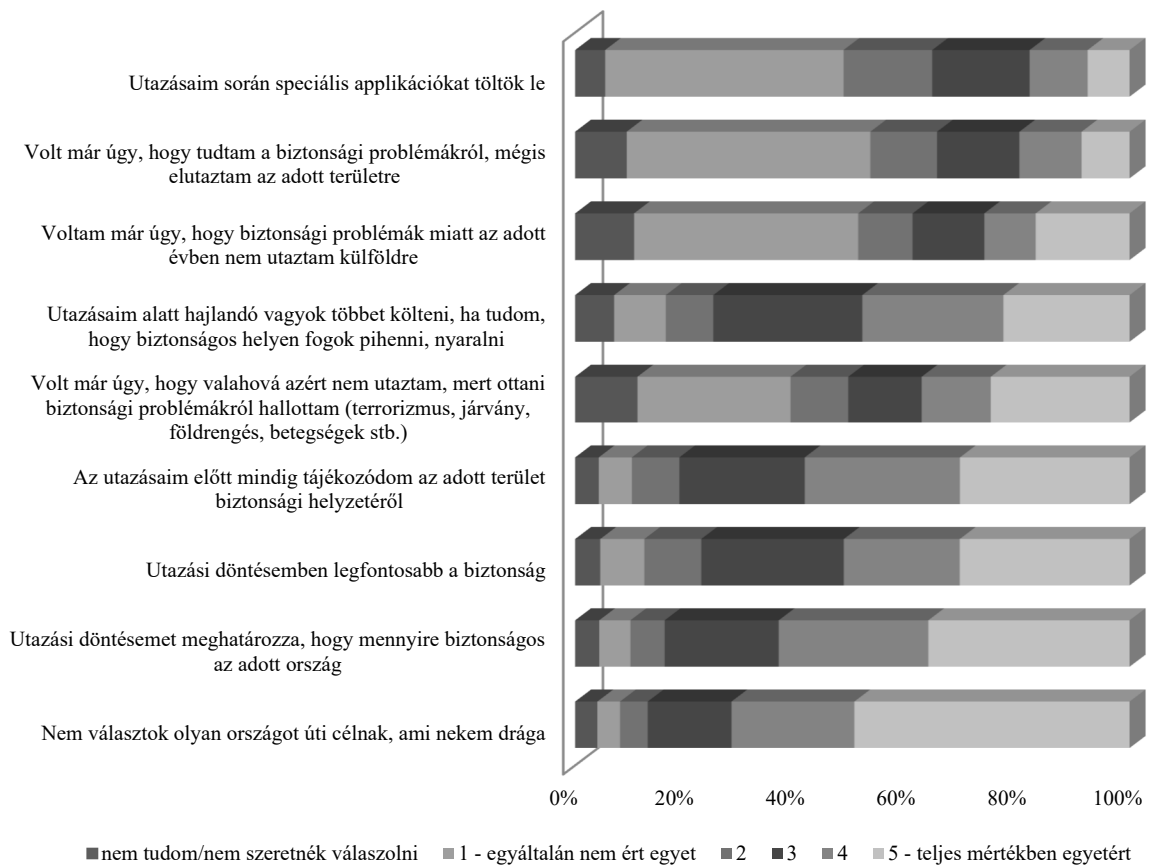


Lektorált tanulmányok

oda. Itt is viszonylag magas volt a nem válaszolók aránya $(9 \%)$. Az utazáson részt vevók legnagyobb része ( $44 \%, 477$ fő) az állítással egyáltalán nem értett egyet, tehát ha tudott valamilyen biztonsági problémáról, akkor nem ment el az adott területre. Ezzel ellentétben 9\%-uk (94 fó) viszont akkor is egyértelmúen elutazott az adott helyre, ha volt tudomása valamilyen biztonsági problémáról.

A következókben azt firtattuk, hogy volt-e már úgy a válaszadó életében, hogy biztonsági problémák miatt az adott évben nem utazott külföldre. Itt ismét magas volt a nem válaszolók aránya (11\%, 115 fó), a válaszadók legnagyobb csoportja pedig (40\%, 439 fő) egyáltalán nem járt még úgy, hogy különböző biztonsági okok miatt nem utazott el az adott évben. Ezzel szemben azok aránya, akik már egyértelmúen jártak így, 17\% volt (184 fó).

A megkérdezett válaszadók legnagyobb csoportjának (30\%, 332 fó) utazási döntéseinél a legfontosabb a biztonság kérdése, a biztonságot teljes mértékben negligálók aránya mindössze 8\% 86 fő). Ennél a kérdésnél elég magas volt a bizonytalanok aránya, mivel az állítással 21\% (227fó) inkább egyetértett (4-es értéket adott), míg 26\% (279 fó) inkább nem. A témakör utolsó kérdése kapcsán szintén a köztes értékek lettek erôsek, hiszen utazásai alatt a megkérdezettek 23\%-a (247 fó) hajlan- dó többet is költeni, ha tudja, hogy biztonságos helyen fog pihenni, az ezt teljes mértékben elutasítók aránya pedig 9\% (101 fó) volt. A két meghatározó csoportot az inkább egyetértők (4-es értéket adók) és a középértéket adók adták, $25 \%$ és $27 \%$-kal (276 fő, illetve 292 fó).

A demográfiai háttérelemzések bemutatása során azt vizsgáljuk, hogy a kérdések kapcsán az egyes demográfiai csoportok válaszaiban vannak-e statisztikailag igazolható eltérések. A háttérelemzést öt változó mentén végeztük el (nem, generációk, lakóhely településtípusa, iskolai végzettség foka és jövedelmi helyzet szubjektív megítélése). A tanulmányban csak azon eredményeket közöljük, melyek statisztikai értelemben véve szignifikáns eltéréseket mutattak.

Az utazási döntésében a biztonság a legfontosabb az alacsony végzettségúeknél, ami folyamatos csökkenés mellett válik a legkevésbé fontossá a magas iskolázottsággal rendelkező válaszadóknál (2. ábra). Ugyanilyen csökkenés mutatható ki annál az állításnál is, hogy „Utazásaim alatt hajlandó vagyok többet költeni, ha tudom, hogy biztonságos helyen fogok pihenni, nyaralni.". Ezzel az állítással a válaszadók közül szintén az alacsony végzettségúek értettek egyet leginkább, és folyamatos csökkenést mutatva a legmagasabb végzettségúek a legkevésbé.

Az „Utazási döntésemet meghatározza, hogy mennyire biztonságos az adott ország." állításra adott válaszok megoszlása (\%) az iskolázottság tekintetében

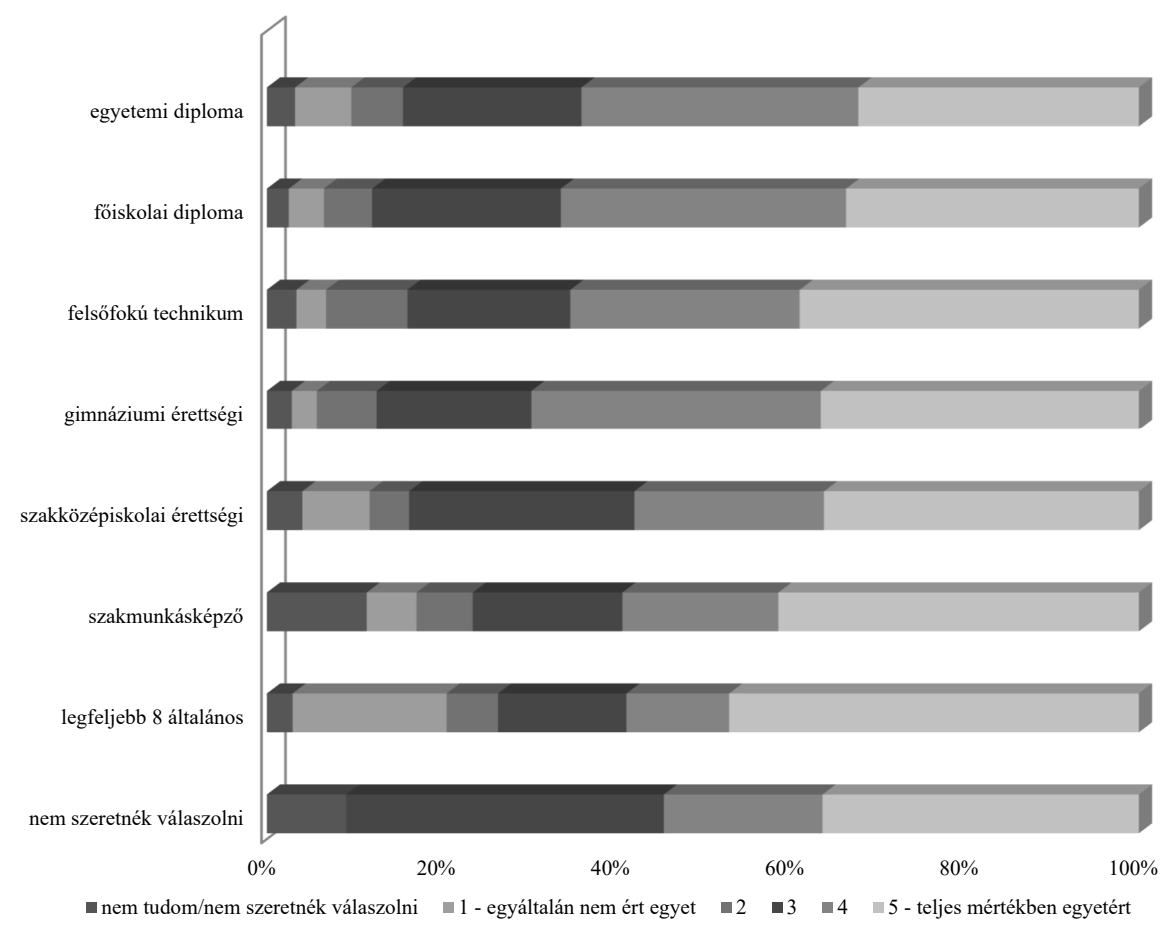

Forrás: saját szerkesztés 


\section{"Egyre inkább jellemző rám, hogy biztonságos helyre akarok utazni."} állítás háttérelemzése

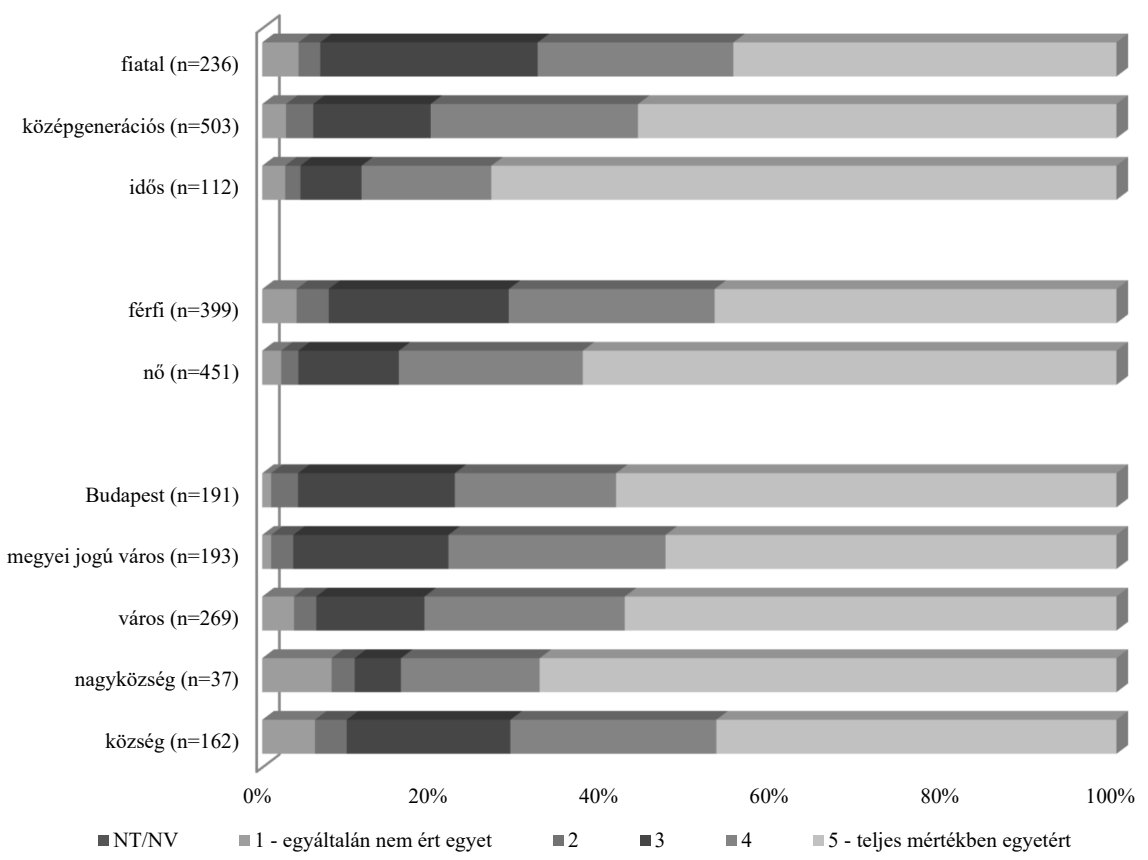

A kérdések többségénél nem lehetett kimutatni összefüggést a válaszok és a jövedelmi viszonyok közt, kivéve a „Volt már úgy, hogy tudtam a biztonsági problémákról, mégis elutaztam az adott területre." állítást, amellyel legkevésbé a kiemelten jómódúak, leginkább pedig a legrosszabb anyagi körülmények közt lévók értettek egyet.

A jövedelem csökkenésével párhuzamosan a válaszadók egyre inkább egyetértettek azzal az állítással, hogy „Voltam már úgy, hogy biztonsági problémák miatt az adott évben nem utaztam külföldre.".

Megjegyzendő, hogy az alacsonyabb jövedelmi szinten élő́k vélelmezhetóen megfelelési nyomást is érzékeltek, ezért lehet a véleményük több esetben ellentmondásban a helyzetükből következtethetô válaszaikkal.

Azzal az állítással, hogy „Utazási döntésemet meghatározza, hogy mennyire biztonságos az adott ország.", 10\%-kal több nő értett egyet, mint férfi. Ugyan csak 5\%-os különbséggel, de azzal az állítással is inkább a nők értettek egyet, hogy „Volt már úgy, hogy valahová azért nem utaztam, mert ottani biztonsági problémákról hallottam (terrorizmus, járvány, földrengés, betegségek stb.).”.

Az elutasítás mértéke mintegy 13\%-kal magasabb a nók körében arra az állításra vonatkozóan, hogy „Volt már úgy, hogy tudtam a biztonsági problémákról, mégis elutaztam az adott területre.". Szintén a nők értettek egyet inkább - ugyan csak 5\%-os különbséggel - azzal az állítással is, hogy „Voltam már úgy, hogy biztonsági problémák miatt az adott évben nem utaztam külföldre.".

Inkább a nők értettek egyet azzal az állítással, hogy „Utazási döntésemben legfontosabb a biztonság." és azzal is, hogy „Utazásaim alatt hajlandó vagyok többet költeni, ha tudom, hogy biztonságos helyen fogok pihenni, nyaralni.".

Utazásaik során speciális applikációkat leginkább a fiatal generáció tagjai töltenek le, míg legkevésbé az idósek. A fiatalok értenek egyet a legkevésbé (bár nem nagy különbséggel) azzal, hogy „Nem választok olyan országot úti célnak, ami nekem drága.".

$\mathrm{Az}$ online megkérdezés eredményeinek kapcsán megállapítható, hogy a biztonságos úti cél preferálása leginkább a nókre jellemzô, hiszen a hölgyek több mint $60 \%$-a szerint ez az állítás nagyon fontos az utazásik folyamán. Ezzel szemben a férfiaknak csak $47 \%$-a értett teljes mértékben egyet az állítással.

A lakóhely típusa alapján leginkább a nagyközségekben élókre jellemzố, hogy biztonságos helyre akarnak utazni (68\%), a Budapesten, városokban és megyei jogú városokban élőknél ez az arány közel azonos 53\%-58\% közötti. 
Lektorált tanulmányok

A kor tekintetében az előzetes várakozásainknak megfelelóen minél idősebb valaki, annál inkább jellemzi a biztonságos úti célok iránti igény, illetve megfordítva, minél fiatalabb, annál kevésbé (3. ábra).

\section{5. Összefoglalás}

A biztonság kérdése több trend hatására egyre fontosabbá válik napjainkban. A globalitás a gondolkodást formálva hozza közel az egyébként nagyon távoli történéseket, hiszen a világfolyamatok hatással vannak a magyar lakosság magatartására is. Az úti célok esetében mind reálisabb az exkluzív helyszínek elérése, és úgy tûnik a vágyak felkeltésének nincs határa, hisz az új konstrukciójú légitársaságok ezt ösztönzik. A távoli helyszínekkel kapcsolatban azonban kevés a tapasztalat, így fokozott figyelmet igényel a biztonság. A digitalizáció, a digitális kultúra térnyerésével öszszekapcsolódhatnak a fizikailag egymástól távol élő fogyasztók, befolyást gyakorolva egymás döntéseire, értékeléseket, akár szálláslehetőségeket, étkezéseket, programokat biztosítva egymásnak. A megosztás terjedése a bizalom meglétét feltételezi, ami a biztonság kérdésének pozitív értelmú interpretációja. A média, mint vágykeltó, töretlenül biztosítja a tartalmakat, amelyek cselekvésre bírják az embereket, ugyanakkor közvetíti a megfontolást érdemló vészhíreket is. Mindent összevetve, számos trend támogatja a turizmus meggyőző növekedési eredményeit.

A turizmus résztvevói számára mindig is szerepelt a döntési szempontok között a biztonság. Miután azonban a többség korábban jól behatárolt, inkább közeli helyszínek felé irányuló döntést hozott, igazán nem volt kérdés a biztonság, mert beláthatóak voltak a körülmények. A kevés kalandor esetében, akiknél ez mégis felmerült, ott a biztonságot felülírta az élménykeresés, a kíváncsiság. Ma, a kiterjedt választási lehetôségek világában már tudatosan kell foglalkozni a biztonság kérdésével, a döntéshozatalban értékelni kell a biztonsági szempontot. Az értékelés egyrészt történhet egy desztinációra vonatkozóan általánosságban, amit gyakran a sztereotípiák támogatnak, másrészt mérlegelni kell a biztonsági kockázat esetlegesen várható szituációs lehetőségét, ami nehezebb feladat, főleg, ha a bizonytalanabb státusú desztinációk esetében az árak hirtelen vonzóvá válnak.

A tanulmányban a turizmus és biztonság témaköréhez illeszkedő legfrissebb hazai utazási attitúdöket vizsgáltuk, melyet a korral, nemmel, jövedelmi különbségekkel, lakhellyel és iskolázottsággal kapcsolatos különbségek vizsgálatára is kiterjesztettünk.
A megkérdezett válaszadók legnagyobb csoportjának (30\%, 332 fó) utazási döntéseinél a biztonság kérdése a legfontosabb, míg a biztonságot teljes mértékben negligálók aránya mindössze 8\% (86 fó). Vizsgálatainkból kiderül az is, hogy a döntéshozatal során a megkérdezettek számára fontos, hogy az adott ország biztonságos-e. A legtöbben (36\%, 394 fó) teljes mértékben egyetértettek az állítással, de a 3-as és 4-es értékeket adók száma is magas volt (21\%, illetve $27 \%)$. A válaszadók döntő többsége nem él a modern információ-kommunikációs eszközökkel, lehetőségekkel, nem tölt le applikációkat, amelyek segíthetnék utazásaikat, mindössze $8 \%$ esetében mutatkozik határozottan ezek alkalmazása. A válaszadók 28\%-a (300fô) úgy nyilatkozott, hogy még sosem járt úgy az utazásai során, hogy biztonsági problémák miatt ne utazott volna el. A második legnagyobb sokaság az ezzel éppen ellentétes tapasztalatú csoport volt, hiszen a válaszadók $25 \%$-ával már megtörtént, hogy valamely biztonsági probléma miatt nem utazott el egy területre. Nyilván, sokat segített volna az értelmezésben, ha tudjuk, hogy ezek a helyzetek miképp és mikor következtek be, elég, ha csak a délszláv háborúra gondolunk, ami sokak döntését határozta meg több éven keresztül.

Megkérdeztük, volt-e már úgy a válaszadók életében, hogy tudtak a választott turisztikai desztinációban egy adott biztonsági problémáról, ennek ellenére mégis elutaztak oda. Ebben az esetben 9\% (94 fö) volt azok aránya, akik akkor is elutaztak az adott helyre, ha tudomásuk volt valamilyen biztonsági problémáról. Az is kérdésünk volt, hogy volt-e már, hogy biztonsági problémák miatt az adott évben valaki egyáltalán nem utazott külföldre. A válaszadók legnagyobb csoportja $(40 \%, 439$ fő) egyáltalán nem járt még úgy, hogy különböző biztonsági okok miatt nem utazott el az adott évben. Ezzel szemben azok aránya, akik már egyértelmúen jártak így, 17\% volt (184 fó).

Fentiek mellett demográfiai háttérelemzéseket is végeztünk az utazási döntések és a biztonság tekintetében. Egyértelmú eredmény, hogy a nők karakteres eltéréseket mutatva érzékenyebben reagálnak erre a témakörre.

Arra jutottunk még, hogy ez a kérdés az alacsony iskolai végzettségúeknél fontosabb szempont, mint a magas iskolázottsággal rendelkező válaszadóknál. Az eredmény adódhat abból, hogy a magasabb iskolázottság általában nagyobb jövedelemmel párosul, így a problémás helyzetek megoldását egyszerúbbnek ítélhetik.

Ha a generációk és a biztonság kérdését vizsgáljuk, akkor világos, hogy a fiatalok bevállalósabbak, vagyis minél idősebb valaki, annál inkább jellemzi a biztonságos úti célok iránti igény. 


\section{Köszönetnyilvánítás}

A kutatást az Emberi Erőforrások Minisztériumának Felsőoktatási Intézményi Kiválósági Programja finanszírozta, a Pécsi Tudományegyetem 4. tématerületi „A hazai vállalatok szerepének növelése a nemzet újraiparosításában" programja keretében (szerződés száma: 20765-3/2018/ FEKUTSTRAT)". A kutatás továbbá az EFOP3.6.1-16-2016-00004 „Átfogó fejlesztések a Pécsi Tudományegyetemen az intelligens szakosodás megvalósítása érdekében" pályázat támogatásával készült el.

\section{Felhasznált irodalom}

AUBERT A. (2010): A globális turizmus jellemzői és trendjei geográfiai megközelítésben. In: Tóth J. (szerk.): Világföldrajz. Akadémiai Kiadó, Budapest. pp. 646-666.

AUBERT A. - CSAPÓ J. - GONDA T. - HEGEDÜS V. - SZABÓ G. (2007a): Turizmus és a terület-, valamint vidékfejlesztés. In: Aubert A. (szerk.): A térségi turizmuskutatás és tervezés módszerei, eredményei. Pécsi Tudományegyetem, Természettudományi Kar, Földrajzi Intézet, Pécs. pp. 76-132.

AUBERT A. - CSAPÓ J. - SZABÓ G. (2007b): A geográfia és a turizmus területi aspektusai. In: Aubert A. (szerk.): A térségi turizmuskutatás és tervezés módszerei, eredményei. Pécsi Tudományegyetem, Természettudományi Kar, Földrajzi Intézet, Pécs. pp. 133-156.

BIANCHI, C. (2016): Solo Holiday Travellers: Motivators and Drivers of Satisfaction and Dissatisfaction. International Journal of Tourism Research. 18(2). pp. 197-208.

BOGÁROMI, E. - MALOTA, E. (2017): Perception of Hungary in terms of security and touristic destination choice - country image of Hungary in 8 countries. In: Németh K. - Péter E. - Kiglics N. (szerk.): II. Turizmus és Biztonság Nemzetközi Tudományos Konferencia. Nagykanizsa. Lektorált online kötet. pp. 180-189.

BUJDOSÓ Z. - GYÖRKI M. (2011): A biztonság szerepe a turizmusfejlesztésben. Acta Carolus Robertus. 1(2). pp. 45-55.

DÁVID L. - MOLNÁR F. - BUJDOSÓ Z. DERESKEY A. (2007): Biztonság, terrorizmus, turizmus. Gazdálkodás. 51(20). pp. 160-166.

DÁVID L. - KOVÁCS T. - TÓTH G. - BUJDOSÓ Z. - PATKÓS CS. (2010): A turizmus hatásai és jelentôsége a területfejlesztésben. In: Süli-Zakar I. (szerk.): A terület-és településfejlesztés alapjai II. Dialóg Campus Kiadó, Pécs. pp. 447-466.
DÁVID L. - KOVÁCS GY. (2012): Innováció a turizmusban. In: Dinya L. - Némethy S. - Nyíri A. (szerk.): Zöld társadalom, zöld gazdaság, innováció. Konferenciakötet. Károly Róbert Főiskola, Gyöngyös. pp. 29-33.

GERDESICS V. (2017): Horvátország (ország) imázsa az EU-csatlakozás időszakában: Balkán vagy Európa? Doktori (PhD) értekezés. Pécsi Tudományegyetem, Közgazdaságtudományi Kar, Regionális Politika és Gazdaságtan Doktori Iskola, Pécs.

GONDA T. (2016): A turisztikai termékfejlesztés elméleti alapjai. PTE Kultúratudományi, Pedagógusképző és Vidékfejlesztési Kar, Szekszárd.

HALL, C. M. (2004): Spatial analysis: A critical tool for tourism geographies. In: Wilson, J. (ed): The Routledge Handbook of Tourism Geographies. Routledge, London. pp. 163-173.

HALL, C. M. - TIMOTHY, D. J. - TIMOTHY, D. D. (eds) (2003): Safety and security in tourism: Relationships, Management and Marketing. Routledge, New York USA-London UK.

HEIMTUN, B. - ABELSEN, B. (2014): Singles and solo travel: Gender and type of holiday. Tourism, Culture E Communication. 13(3). pp. 161-174.

LENGYEL M. (2004): A turizmus általános elmélete. KIT-HFF, Budapest.

LEW, C. M. - HALL, C. M. - TIMOTHY, D. (2008): World Geography of Travel and Tourism: A Regional Approach. Elsevier, Oxford.

MAWBY, R. I. (2000): Tourists' perceptions of security: the risk-fear paradox. Tourism Economics. 6(2). pp. 109-121.

MEYER, M. (2011): Tourism versus spatial order: mutual relations. Tourism. 21(1-2). pp. 25-32.

MICHALKÓ G. (2010): Boldogító utazás: a turizmus és az életminóség kapcsolatának magyarországi vonatkozásai. MTA Földrajztudományi Kutatóintézet, Budapest.

MICHALKÓ G. (2012): Turizmológia: elméleti alapok. Akadémiai Kiadó, Budapest.

SCOTT, N. - LAWS, E. - PRIDEAUX, B. (eds) (2010): Safety and Security in Tourism: Recovery Marketing After Crises. Routledge.

SÖNMEZ, S. F. - GRAEFE, A. R. (1998): Influence of terrorism on foreign tourism decisions. Annals of Tourism Research. 25(1). pp. 112-144.

TARLOW, P. E. (2014): Tourism security. Strategies for Effectively Managing Travel Risk and Safety. Butterworth-Heinemann, Weltham USAOxford UK.

TÖRŐCSIK M. - CSAPÓ J. (2018): Fogyasztói trendek hatása a turizmusra. In: Csapó J. Gerdesics V. - Törő́csik M. (szerk.): Generációk a 
turizmusban. I. Nemzetközi Turizmusmarketing Konferencia. Tanulmánykötet. Pécsi Tudományegyetem, Közgazdaságtudományi Kar, Pécs. pp. 8-22.

TÖRÓCSIK M. - JAKOPÁNECZ E. (2011): A fogyasztói félelem - kockázatészleléstól az ellenállásig. In: Fojtik J. (szerk.): Felelós marketing. MOK 2011: A Magyar Marketing Szövetség Marketing Oktatók Klubja 17. országos konferenciája. Pécsi Tudományegyetem Közgazdaságtudományi Kar, Pécs. pp. 13-21.
WILKS, J. - PENDERGAST, D. - LEGGAT, P. (eds) (2011): Tourism in Turbulent Times - Towards Safe Experiences for Visitors. Routledge, New York USA.

\section{Internetes forrás}

MAGYAR TURISZTIKAI ÜGYNÖKSÉG (2017): Nemzeti Turizmusfejlesztési Stratégia 2030. http:// www.kormany.hu/download/8/19/31000/mtu_kiadvany_EPUB_297x210mm\%20-\%20preview.pdf, Letöltve: 2018. április 3. 